\title{
Not Playing Second Fiddle: A Librarian as Adjunct Professor for a University Music Department
}

\author{
By Gillian Nowlan
}

\section{Introduction}

Most music librarians have, at one time or another, been asked to perform the tricky task of delivering one-shot library sessions. Not only can it be difficult to cover everything students need to know about the library in one or two hours, but it is hard to foster a connection with both students and faculty in such short and brief interactions. One way to combat this is by serving as an adjunct professor. This provides the opportunity to form a richer and deeper connection with students and faculty which is usually not possible during a typical reference desk interaction or single instruction session. ${ }^{1}$

This paper will look at one librarian's experience as an adjunct professor in an academic music department, including the process of becoming an adjunct professor, some of the challenges this can bring, and the different ways it can impact and benefit relationships with students and faculty members.

\section{One Librarian's Experience}

As a liaison librarian at the University of Regina I have multiple responsibilities, particularly in my assigned subject areas of education, media production and studies, and music. Because of my undergraduate training in music, I found liaising with faculty and students in the music department very natural. We possessed the same language and understanding of some of the challenges of studying music. Although I had established a connection with this department, I was still struggling to further incorporate information literacy into music classes and develop a greater understanding of challenges faculty were facing: how classes were run, how I could better assist as their liaison librarian, and how to better connect with students needing assistance. As I pondered how I could better offer services to this department, a faculty member in the music department approached me asking if I would be willing to co-teach two classes with her in the upcoming term. In this instance I had great support from my fellow colleague in the music department, who requested that I be granted an adjunct position within the department, allowing me to co-teach in undergraduate

Gillian Nowlan is the Music, Education, and Film Liaison Librarian at the University of Regina Library.

1. Janet Swan Hill, "Wearing Our Own Clothes: Librarians as Faculty," Journal of Academic Librarianship 20, no. 2 (1994): 71-76. 
courses. I was lucky; while sometimes faculty will approach you about this, more often they will not. Sitting down with faculty members and demonstrating in department meetings how information literacy can be rolled into specific classes, and the benefits students can reap from developing these skills, can help influence the department to offer this type of position to you or allow you to help co-teach.

Once my position was finalized, my first plan of action was to meet with the music faculty member and look closely at the class syllabus in order to gain a better understanding of the information literacy goals for students that semester. I would be co-teaching in two courses (second-year and fourth-year music history courses). Goals for the second-year music history course included being able to use the library catalogue to locate monographs, scores, and musical recordings, becoming familiar with music databases, being more fluent with the Chicago citation style, and gaining knowledge about peer-reviewed journal articles. Goals for the fourth-year music history class included learning how to properly evaluate and assess online resources, understanding the basics of Canada copyright and how it applies to music resources, and using bibliometrics.

Once specific goals were established, it was clear how to carve out a plan that would incorporate the desired information literacy objectives. The faculty member and I decided that one assignment would be dedicated to information literacy in the second-year course and two in the fourth-year course. Two full in-class sessions would focus on the skills that would be required to complete the assignment in the second-year course, and I met individually with students in the fourth-year course because of low registration. Each second-year class and fourth-year individual session focused on taking students through library resources and services that would help them complete the assignments and on demonstrating certain concepts they would need to grasp in order to do well on their final paper. The assignments were built before my lesson plans were developed to ensure my lesson plan would include all the elements that would be required to complete each assignment.

During that semester I set up specific office hours for students in both classes to make sure they had plenty of opportunities to ask questions after the sessions and while they were working on assignments. Once all the assignments were completed and submitted, I used a clear and simple rubric that would provide consistent guidelines for my marking. Marks for both assignments were high and it appeared that the students had a good grasp of the elements and goals we had set out in the planning for the course. Overall the experience was a very positive one, and at the end of the term I felt like I had made some great connections and developed a better understanding of the students and faculty in that department.

\section{Not Playing Second Fiddlle}

There is still debate about whether librarians belong in the classroom or if they should even hold faculty status. Although this is still a contentious area in the profession, both the literature and my 
own personal experience show clear benefits in serving as an adjunct professor within an academic department. Teaching as an adjunct can also help change how faculty members view librarians and enhance perceptions of librarians as educators. ${ }^{2}$ Some of the biggest rewards arising from adjunct participation in classrooms are the long-term relationships that are created with students. These relationships help build trust with students and also help them see how a librarian can assist them in their studies. For the librarian, it can help demystify some of the behaviours of the student researcher. More time co-teaching students helps librarians see the cognitive, technological, emotional, and physical roadblocks they encounter. ${ }^{3}$ Though there is no such thing as the "typical student researcher," a more in-depth classroom experience with students can help librarians see some of the most common problems and issues students face and identify what services or resources can help mediate certain gaps. ${ }^{4}$ Teaching an entire course also allows librarians to survey the group throughout the term and find out what students like and dislike about your teaching style, the assignments given, how the class and syllabus is organized and so on. Overall, this feedback will improve your confidence as an instructor and provide some valuable and constructive feedback on how to improve your teaching methods and techniques.

Co-instructing courses helps build strong relationships not only with students but also with faculty. Librarians can work towards developing a better understanding of faculty work. This can help create a better and more thorough understanding of some of the challenges faculty face on a daily basis, such as balancing workloads, preparing classes, creating assignments, and publishing. ${ }^{5}$ Librarians can take this knowledge and use it to offer library services that are better tailored to fit the needs of the university community, fill gaps in the collection or build certain areas (for example, materials required for students to complete assignments), and better understand the information literacy requirements expected of students. ${ }^{6}$

\section{Isn’t Being a Librarian Enough?}

Some might wonder, as Jane Kemp asks in the title of her article, "isn't being a librarian enough?" Although there are many benefits to being an adjunct professor for a department, there are certainly some challenges that come with this added responsibility. Taking on this added role is a big time commitment. Not only are there more classes to teach, but time needs to be taken to create a syllabus, build assignments, meet more frequently with students, grade student work, and prepare lectures. This can also affect time scheduling within your library work environment and

2. Adam Balcziunas and Larissa Gordon, "Walking a Mile in Their Shoes: Librarians as Teaching Faculty," College \& Research Libraries News 73, no. 4 (2012): 192-195.

3. Kimberley Donnelly, "Reflections on What Happens When Librarians Become Teachers," Computers in Libraries 20, no. 3 (2000): 46-49.

4. Kathy Campbell, "When a Librarian Enters the Classroom: My Experiences Teaching a Freshman Experience Class," College \& Research Libraries News 69, no. 10 (2008): 606-617.

5. Balcziunas and Gordon, "Walking a Mile."

6. Jane Kemp, "Isn't Being a Librarian Enough? Librarians as Classroom Teachers," College \& Undergraduate Libraries 13, no. 3 (2006): 3-23. 
make prior work commitments more challenging to organize. Depending on the workload of the course it is best to examine your schedule and decide if there are items you are willing and able to let go of or if there is any flexibility to your schedule or assigned duties. There is also some flexibility in duties as an adjunct. Being an adjunct professor can involve teaching many classes, or just one. The level of involvement can also be discussed in the beginning stages. If your schedule as a librarian is very heavy, you may only want to participate in the classroom time and leave the marking and assignment creation mostly up to the professor.

\section{Concluding Thoughts}

There are clear benefits to working as an adjunct. This type of position can help solidify connections with your department and strengthen the relationship between that department and the library. These connections are paramount in demonstrating the importance of the library and of librarians on campus and help librarians gain a better understanding of how to offer valuable services to our community.

\section{References}

Balcziunas, Adam, and Larissa Gordon. "Walking a Mile in Their Shoes: Librarians as Teaching Faculty." College \& Research Libraries News 73, no. 4 (2012): 192-195.

Blakeslee, Sarah. "Librarian in a Strange Land: Teaching a Freshman Orientation Course." Reference Services Review 26, no. 2 (1998): 73-78. doi: 10.1108/00907329810307678.

Campbell, Kathy. "When a Librarian Enters the Classroom: My Experiences Teaching a Freshman Experience Class." College \& Research Libraries News 69, no. 10 (2008): 606617.

Donnelly, Kimberley. "Reflections on What Happens When Librarians Become Teachers." Computers in Libraries 20, no. 3 (2000): 46-49.

Hill, Janet Swan. "Wearing Our Own Clothes: Librarians as Faculty." Journal of Academic Librarianship 20, no. 2 (1994): 71-76.

Kemp, Jane. "Isn't Being a Librarian Enough? Librarians as Classroom Teachers." College \& Undergraduate Libraries 13, no. 3 (2006): 3-23. doi: 10.1300/J106v13n03_02. 